\title{
Pelatihan Dasar Public Speaking Untuk Mengembangkan Keterampilan Penyampaian Informasi dan Kepercayan Diri Bagi Siswa Tunarungu
}

\author{
Bunga Asriandhini ${ }^{a, 1 *}$, Merliana Nur Khasidah ${ }^{\text {b,2 }}$, Pramudita Nugraha Adi Kristika ${ }^{\text {c,3 }}$ \\ a,b,c Fakultas Bisnis dan ilmu Sosial, universitas Amikom Purwokerto \\ 1bunga.asriandhini@amikompurwokerto.ac.id, ${ }^{2}$ merliana945@gmail.com \\ ${ }^{3}$ pramuditanugraha01@gmail.com \\ *korespondensi penulis
}

Naskah diterima: 1 September 2020, direvisi: 20 September 2020, disetujui: 27 September 2020

\begin{abstract}
Abstrak
Public Speaking adalah bagian dari soft skill yang mengajarkan mengenai keterampilan berbicara di depan umum. Bagi siswa tunarungu yang memiliki cara khas dalam berkomunikasi, yaitu menggunakan bahasa isyarat, public speaking juga bermanfaat untuk meningkatkan kemampuannya menyampaikan pesan/informasi kepada orang lain baik di lingkungan komunitasnya maupun di lingkungan sosial terbuka ketika mereka terjun ke masyarakat bahkan dalam dunia kerja. Berbasis pada kebutuhan keterampilan penyampaian informasi siswa tunarungu yang disampaikan pihak SLB B Yakut Purwokerto, dosen dan mahasiswa Program Studi Ilmu Komunikasi Universitas Amikom Purwokerto menyelenggarakan pelatihan dasar public speaking untuk siswa tunarungu. Hasil evaluasi yang didapatkan, melalui pelatihan public speaking dengan metode story telling, siswa mengalami peningkatan dalam cara penyampaian informasi terlebih di depan audiens serta peningkatan rasa percaya diri. Siswa tunarungu perlu sering berlatih public speaking secara berkesinambungan agar keterampilan menyampaikan pesan meningkat juga terbiasa berkomunikasi di depan umum, sehingga pada muaranya akan membentuk konsep diri positif dan mendorong eksistensinya dalam masyarakat.
\end{abstract}

Kata-kata kunci: Public Speaking; Pelatihan; Tunarungu

\begin{abstract}
Public speaking is a soft skill expounding speech prowess in front of the audience. Hearing-impaired person requires a special method of communication, namely sign language. Public speaking skills are also beneficial in increasing the speaker's ability to convey information more effectively for people within their community as well as open social environment when they are directly involved in the society or even in their respective working field. Based on a need of ability to convey information for people with hearing impairment mentioned by Special school Yakut Purwokerto (SLB B Yakut Purwoketo), fasilitator team organized basic training of public speaking for students with hearingimpairment. Giving a speech before an audience is an order of magnitude of a challenge for people with hearing-impairment. Assessment results obtained from public speaking training by using the method of storytelling, students experiences an increase in ability to convey information especially in front of the audience in conjunction with a boost in self confidence. Hearing-impired student needs to take more public speaking exercise continually in order to increase their communication skill and ability to speak in front of the audience. Public speaking will form their positive self-concept and encourage their existence in the society.
\end{abstract}

Keywords: Public Speaking; Training; Hearing-impired 


\section{PENDAHULUAN}

We cannot not communicate, manusia tidak dapat tidak berkomunikasi, hal ini merupakan fitrah manusia sebagai makhluk sosial yang berinteraksi untuk memenuhi kebutuhan hidupnya, saling bekerja sama dalam masyarakat guna mencapai tujuan bersama, baik interaksi dengan dirinya sendiri, maupun dengan orang lain secara interpersonal juga kelompok. Berkomunikasi secara verbal dan nonverbal dapat dilakukan oleh siapa saja, namun berkomunikasi di depan audiens memerlukan ilmu khusus (Mulyana, 2019; Wakhyudi, 2019), termasuk bagi kaum difabel. Keterampilan berbicara di depan umum penting dipelajari oleh setiap orang dengan latar belakang apapun, banyak orang yang menempati posisi penting dan sukses di dunia ini adalah seorang pembicara ulung. Berbicara di depan umum bukan hanya sekedar menyampaikan pesan saja, namun juga memperhatikan bagaimana pesan yang disampaikan dapat dimengerti dan masuk ke dalam hati lawan bicara/ audiens.

Public speaking berfokus pada efektivitas pesan yang disampaikan kepada audiens. Komunikasi efektif dalam public speaking didukung oleh beberapa faktor, diantaranya penguasaan materi, kepercayaan diri, mengelola situasi, mengelola audiens, dan penampilan pembicara yang menarik
(Hojanto,2016:22;Noer, 2018). Pembicaraan menjadi powerfull ketika konten yang disampaikan oleh public speaker dapat mempengaruhi pikiran audiens sehingga termanifestasi dalam tindakan (Sirait, 2016:16).

Kebutuhan keterampilan public speaking sebagai soft skill diperlukan juga bagi siswa tunarungu sebagai bagian dari kaum difabel yang selayaknya menjadi perhatian oleh pemerintah dan seluruh lapisan tatanan sosial untuk mendukung kesuksesan perannya di masyarakat termasuk di dunia kerja. Menurut Turistiati (2019) untuk meningkatkan kepercayaan diri ketika terjun ke masyarakat salah satunya dengan meningkatkan soft skill.

Tunarungu adalah individu dengan keterbatasan pendengaran masuk kepada golongan disabilitas, menurut Undangundang Disabilitas No.8 Tahun 2016 termasuk ke dalam disabilitas yaitu orang yang mengalami keterbatasan fisik, intelektual, mental, dan sensorik dalam waktu lama serta mengalami hambatan saat berinteraksi dan kesulitan berpartisipasi penuh.

Siswa tunarungu tingkat menengah termasuk ke dalam usia anak. Menurut Undang-undang No. 23 Tahun 2002 tentang perlindungan anak, pengertian anak adalah 
seseorang yang belum berusia 18 (delapan belas) tahun termasuk janin yang masih berada dalam kandungan. Disimpulkan bahwa anak/siswa tunarungu adalah anak/siswa yang memiliki keterbatasan pendengaran atau sensorik pada usia 0 sampai 18 tahun. Siswa tunarungu memiliki keunikan dalam berkomunikasi, secara verbal mereka menggunakan tulisan dan secara nonverbal mempraktekkan bahasa isyarat sebagai media komunikasinya, baik komunikasi sesama tunarungu maupun dengan orang dengar.

Berkaca dari kisah Hellen Keller pada awalnya lahir normal, sehat, cerdas, hingga di usia 9 tahun suatu penyakit menyebabkannya kehilangan pendengaran dan penglihatannya. Keller seketika menjadi hening dalam sebuah kehidupan, namun bangkit melampaui keterbatasannya. Keller memiliki kemampuan retorika dan menulis yang luar biasa, belajar dari seorang Anne Sullivan sang guru. Pada akhirnya mampu menciptakan karya-karya intelektual (Helen Keller Biography). Kisah ini dapat menjadi motivasi bahwa setiap manusia memiliki keterbatasan, namun manusia dapat melampauinya dan berkarya dengan kekuatan atau potensi yang dimiliki.

Faktor utama kesuksesan dalam public speaking adalah kepercayaan diri. Tantowi Yahya berpendapat bahwa keterampilan ini dipraktikkan dengan memanfaatkan setiap kesempatan. Untuk mendapatkan kepercayaan diri ketika berbicara di depan audiens adalah dengan cara berlatih, tidak ada cara instan untuk mendapatkan kemampuan public speaking (Hojanto,2016: 3;Wakhyudi, 2019).

Kepercayaan diri erat kaitannya dengan konsep diri. Sebelum membangun kepercayaan diri, siswa tunarungu diarahkan terlebih dulu untuk membentuk konsep diri positif sehingga memiliki harga diri yang tinggi (Rakhmat,2019:124).

Beberapa teknik praktis public speaking yang dapat dipraktekkan khususnya bagi siswa tunarungu yaitu: (1) Mengatasi rasa cemas, rasa cemas dan takut timbul karena ketidakbiasaan melakukan suatu hal. Perlu penyesuaian diri baik secara fisik dan mental menghadapi situasi yang belum biasa dilakukan dengan teknik mengubah bahasa tubuh seperti bersikap tegak sehingga memunculkan sikap percaya diri dan mengingat memori positif masa lalu untuk mengubah emosi sekarang.

Menyamankan audiens, dengan cara menghibur, mengajak bermain game atau melontarkan humor. (3) Mengetahui tipe audiens, yaitu mencermati berbagai karakter audiens yang hadir, seperti tipe kritis, tipe diam, tipe pembelajar, dan sebagainya. Tujuannya untuk mengendalikan diri dan 
audiens dengan perbedaan karakter dan keunikannya. (4) Teknik membuka dan menutup yang berkesan. Pembukaan menarik diperlukan untuk membangun first impression di hadapan audiens, dengan menampilkan visual yang menarik, pertanyaan powerfull, dan mengajak peserta berpartisipasi. Penutupan yang berkesan dapat dilakukan dengan pantun, lagu, ajakan, dan cerita. (5) Menghadapi kondisi darurat, perlu dihadapi dengan tenang dan solutif. (6) Penampilan, tujuannya untuk membangun citra diri di hadapan audiens dengan memperhatikan segala sesuatu yang melekat pada tubuh (Hojanto, 2016).

Berdasarkan observasi awal, tim fasilitator mencermati bahwa SLB B Yakut Purwokerto merupakan salah satu sekolah bagi penyandang tunarungu tingkat Taman Kanak-kanak, Sekolah Dasar, dan Sekolah Menengah. Pihak sekolah memiliki perhatian kepada pengembangan cara berkomunikasi dan berinteraksi siswa-siswinya dan menghendaki adanya pembelajaran cara penyampaian pesan/informasi anak tunarungu kepada teman sesama tunarungu juga masyarakat di lingkungan sosialnya.

Pelatihan ini diharapkan dapat melatih keterampilan siswa tunarungu dalam menyampaikan pesan/informasi secara efektif dan dimengerti dengan menggunakan isyarat nonverbal minimal oleh lingkungan terdekatnya. Keterampilan ini bermanfaat bagi anak tunarungu ketika terjun ke masyarakat, lebih jauh lagi menjadikan anak tunarungu lebih mandiri dan membangun kepercayaan dirinya. Siswa tunarungu yang akan diberi pelatihan dibatasi yaitu pada jenjang Sekolah Menengah Pertama dan Sekolah Menengah Atas sejumlah 10 siswa (2 siswa tingkat menengah pertama dan 8 siswa tingkat menengah atas). Persoalan yang ada diatasi dengan memberikan pelatihan dasar public speaking, di mana ilmu tersebut memberikan pengetahuan praktis penyampaian informasi yang menarik.

\section{METODE}

Pelatihan public speaking dilaksanakan di dua tempat. Lokasi pertama di SLB B Yakut Purwokerto, J1. Kolonel Sugiri No.10, Brubahan, Purwanegara, Kec. Purwokerto Utara, Kabupaten Banyumas, Jawa Tengah 53116 pada tanggal 27 dan 28 Agustus 2020. Pada hari ketiga, 31 Agustus 2020 dilaksanakan praktik public speaking di laboratorium broadcasting Universitas Amikom Purwokerto, J1. Letjend Pol. Soemarto, Karang Jambu, Purwanegara, Purwokerto Utara, Kabupaten Banyumas 53217.

Peserta pelatihan adalah siswa tunarungu SLB B Yakut Purwokerto, dua siswa berasal dari sekolah menengah tingkat 
pertama serta delapan siswa dari tingkat sekolah menengah atas. Peserta adalah siswa yang memiliki minat pada bidang public speaking dan siswa dengan kondisi yang diprioritaskan mendapatkan treatment peningkatan keterampilan berkomunikasi dan pengembangan kepercayaan diri.

Berdasarkan permasalahan mitra, metode yang sesuai untuk diterapkan yaitu pelatihan. Harapannya peserta dapat menerima materi dengan baik dan berlatih secara langsung dengan pendampingan tim fasilitator. Pelaksanaannya meliputi (1) Persiapan, (2) Perencanaan metode pembelajaran, (3) Pendekatan subyek, (4) Pelaksanaan pelatihan, (5) Evaluasi.

Pada tahap persiapan, kegiatan yang dilaksanakan berupa observasi, menggali metode pembelajaran siswa tunarungu yang diterapkan di SLB B Yakut Purwokerto, hal ini penting dilakukan agar pelaksanaan pelatihan atau pembelajaran lebih tepat dan mengena pada target (siswa tunarungu). Metode pembelajaran yang digunakan yaitu story telling. Metode ini dipilih karena implementasinya sesuai dengan kondisi siswa tunarungu, sederhana dan mudah dilakukan oleh peserta mengingat pelatihan ini baru pertama kali diikuti. Peserta diminta untuk bercerita pengalaman pribadi di depan audiens dengan mempraktikkan teknik-teknik public speaking.
Pada tahap berikutnya, fasilitator melakukan pendekatan kepada peserta pelatihan, mengenali kondisi psikologis siswa tunarungu dan membangun hubungan awal sehingga timbul rasa percaya dan nyaman terhadap kehadiran tim fasilitator. Fasilitator menyampaikan materi sesuai dengan rencana dan kondisi siswa tunarungu. Tim fasilitator dibantu oleh guru pendamping dari pihak sekolah sejumlah 5 orang. Satu guru mendampingi pemateri untuk menerjemahkan materi ke dalam bahasa isyarat, empat guru mendampingi di setiap kelompok peserta yang dibagi ke dalam 2 kelompok masing-masing berjumlah 5 peserta.

Pada sesi praktik, setiap peserta diberikan kesempatan untuk menunjukkan performanya. satu per satu bercerita di depan audiens. Peserta boleh menggali dan menampilkan bakat untuk mendukung pesan atau informasi yang akan disampaikan kepada audiens.

Pelatihan ini diakhiri dengan evaluasi efektivitas pelatihan secara menyeluruh serta mengukur kebermanfaatan, menelaah bagian yang perlu diperbaiki untuk pengembangan segala aspek pengabdian kepada masyarakat yang lebih baik, terutama untuk pelatihan public speaking bagi siswa berkebutuhan khusus. Selain itu fasilitator juga mengevaluasi secara detail penampilan setiap 
peserta, memberikan feedback kepada pihak sekolah berupa laporan evaluasi individual peserta.

\section{HASIL DAN PEMBAHASAN}

Public speaking biasa dipelajari oleh masyarakat bukan penyandang disabilitas. Berbagai elemen masyarakat dengan beragam profesi berlomba mengikuti pelatihan tersebut, guna meningkatkan kemampuan berbicara di depan umum. Bentuk komunikasi ini diperlukan dalam profesi apapun, bahkan setiap orang dapat menerapkan ilmu public speaking dalam berinteraksi di lingkungan masyarakat seharihari.

Pelatihan ini menjadi menarik karena diselenggarakan untuk siswa-siswi tunarungu di mana para siswa ini memiliki cara berkomunikasi yang unik, yaitu menggunakan bahasa isyarat. Ciri khas berkomunikasi ini menjadi tantangan tersendiri bagi tim fasilitator dan peserta.

Pada orang dengar, keberhasilan public speaking salah satunya dipengaruhi oleh teknik vokal yang baik, seperti intonasi yang sesuai, suara yang bulat, juga enak didengar. Tiga kekuatan dalam berkomunikasi, yaitu verbal, vokal, dan visual (Wakhyudi, 2019: 21). Faktor tersebut menentukan apakah seorang pembicara berhasil menyampaikan gagasannya atau bahkan sama sekali tidak berpengaruh pada audiens.

$$
\text { Pembicara ulung seperti mantan }
$$

presiden Amerika Serikat Barrack Obama melakukan orasi memukau sanggup meyakinkan calon pemilih pada rangkaian acara pemilihan presiden. Tinggi rendah suara, penekanan pada kata tertentu, memberikan efek pada penerimaan pesan atau informasi yang disampaikan. Begitu pula dengan mantan Presiden Republik Indonesia pertama Ir. Soekarno, dengan pidatonya yang berapi-api mampu membangunkan kekuatan rakyat untuk merebut kemerdekaan bangsa Indonesia. Berbeda dengan Aa Gym seorang penceramah dengan kelembutan suara yang mendayu membuat sejuk orang yang mendengarnya, mampu menggambarkan sisi kedirian yang lemah dihadapan sang pencipta hingga jama'ahnya menitikkan air mata.

Berinteraksi dalam lingkungan masyarakat pun memerlukan keterampilan berkomunikasi, pun dalam lingkungan terkecil yaitu keluarga. Keterampilan berbicara bukan hanya sekedar menyampaikan pesan, namun suatu cara agar pesan tersebut disampaikan secara efektif.

Siswa tunarungu memiliki keterbatasan dalam berkomunikasi secara verbal. Berdasarkan hasil observasi ditemukan bahwa keterbatasan tersebut melahirkan konsep diri negatif, diantaranya menganggap 
diri tidak sempurna, malu, dan merasa tidak diterima dalam masyarakat. Persepsi tersebut menurunkan rasa percaya diri. Berlaku sebaliknya, kepercayaan diri lahir dari konsep diri positif (Rakhmat, 2019:124).

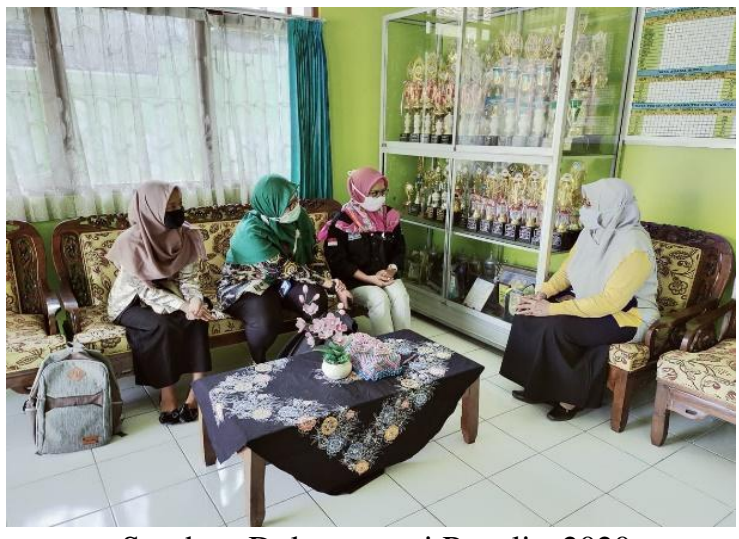

Sumber: Dokumentasi Penulis, 2020

Gambar 1. Tahap Observasi

Pada awal kegiatan, penting dilakukan yakni menginternalisasi nilai-nilai positif ke dalam diri siswa tunarungu, bertujuan mengangkat harga diri peserta untuk membangun konsep diri positif. Beberapa siswa terlihat memiliki kepercayaan diri kuat, disebabkan pola pengasuhan dalam keluarga serta pengaruh lingkungan dalam pembentukan karakter. Sebagian besar cenderung masih perlu diberikan motivasi agar dapat membangun konsep diri positif. Konsep diri adalah cara seseorang mempersepsi dirinya berdasarkan persepsi orang lain dan penilaiannya terhadap diri sendiri (Rakhmat, 2019:124).

Penanaman nilai diri positif pada tunarungu perlu treatment berbeda. Stereotip dan stigma negatif yang terlanjur dilekatkan masyarakat pada diri tunarungu berdampak terhadap cara tunarungu mempersepsi dirinya. Pada pelaksanaannya, fasilitator perlu meyakinkan dengan cara yang tidak melukai kediriannya. Bagian ini penting dilakukan karena untuk bisa berbicara di depan umum perlu kepercayaan diri yang kuat, meyakinkan peserta terhadap potensi dirinya akan menumbuhkan percaya diri yang kuat.

Nilai-nilai positif yang diinternalisasikan diantaranya tentang keunikan berkomunikasi, kelebihan dalam bidang yang berorientasi visual dan kinestetik, serta penguatan yang berfokus terhadap potensi bukan pada keterbatasan.

Pada kesempatan berikutnya, tim fasilitator memberikan materi mengenai konsep dasar public speaking. Materi disajikan dalam dua versi, yaitu penyajian materi secara langsung oleh fasilitator kepada peserta didampingi oleh guru pendamping sebagai penerjemah, selain itu fasilitator juga menyajikan materi berupa tulisan dengan format power point yang ditampilkan saat pelatihan sebagai pendukung penyampaian materi. Poin utama dalam materi yang disampaikan yaitu melatih kejelasan informasi serta menumbuh kembangkan rasa percaya diri menyampaikan pesan secara efektif di depan umum. 
Penyajian materi disesuaikan dengan gaya belajar visual siswa tunarungu. Secara umum, peserta dapat memahami materi yang diberikan. Antusiasme peserta terlihat ketika mereka menyimak dengan seksama dan mengajukan pertanyaan. Pertanyaan peserta diantaranya seputar cara menghilangkan gugup di atas panggung dan bagaimana cara untuk meningkatkan rasa percaya diri. Pelatihan ini sejalan dengan kebutuhan dan keinginan peserta untuk meningkatkan keterampilan berkomunikasi.

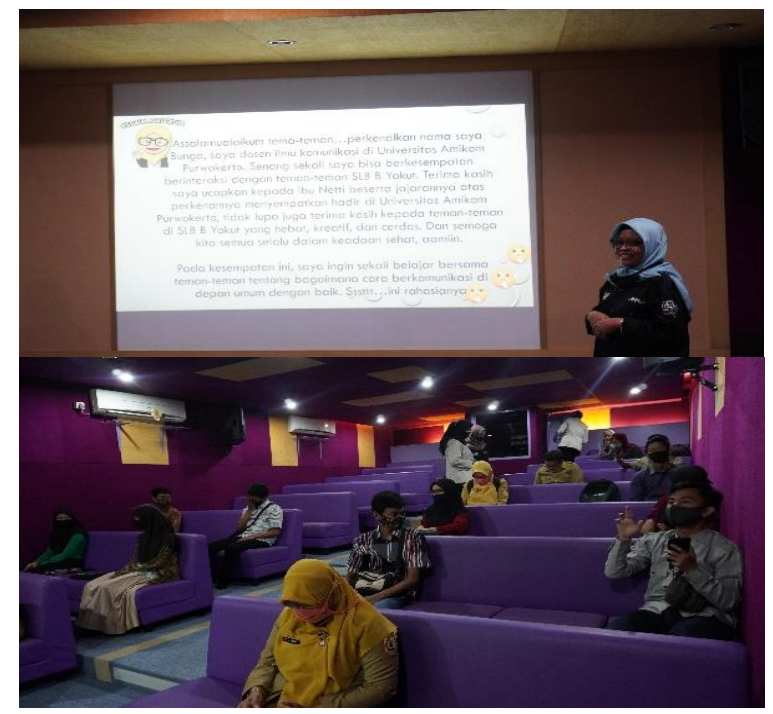

Sumber: Dokumentasi Penulis, 2020

Gambar 2. Penyampaian materi

Pada kegiatan ini, siswa diminta untuk mengangkat sebuah ide cerita dengan tema “pengalamanku”. Masing-masing siswa mengajukan satu topik materi terkait dengan pengalaman profesional, prestasi, dan pengalaman hidup. Materi yang diangkat oleh masing-masing peserta disesuaikan dengan minat, pengalaman, dan bakat agar peserta menguasai materi dengan mudah. Alasan lain pemilihan tema, untuk menaikan harga diri peserta dengan menceritakan prestasi, pengalaman berharga, dan bakatnya diharapkan dapat membantu menumbuhkan rasa percaya dirinya.

Sepuluh peserta secara satu per satu mengimplementasikan konsep serta teknik dasar public speaking dengan mempraktekkan secara langsung bercerita di depan fasilitator, guru, dan teman-temannya, seluruh tampilan peserta didokumentasikan. Peserta mengambangkan ide cerita dan menyusun materi presentasi. Tahapan ini melatih keterampilan siswa dalam menuangkan gagasan secara verbal dalam bentuk tulisan. Tunarungu memiliki keterbatasan dalam olah verbal, hal ini disampaikan pula oleh Kepala SLB B Yakut Purwokerto. Kendala yang muncul adalah perlu waktu lama saat menuliskan materi. Solusinya, guru pendamping membimbing peserta dan mengarahkan menuliskan ide.

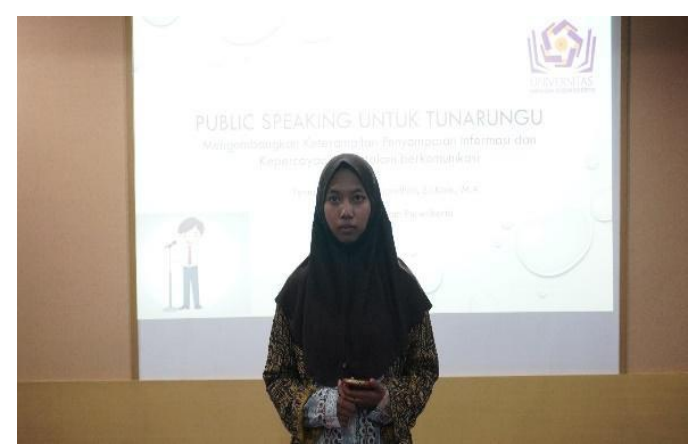

Sumber: Dokumantasi Penulis, 2020

Gambar 3. Praktik Public Speaking Siswa Tunarungu 
Praktik berlangsung di laboratorium broadcasting atau mini bioskop Universitas Amikom Purwokerto. Peserta menggunakan metode story telling menggunakan bahasa isyarat. Salah satu keunikan bahasa isyarat ialah memiliki kekuatan pada penggunaan ekspresi. Pesan nonverbal seringkali dikatakan memiliki pengaruh besar dalam komunikasi, berfungsi untuk menguatkan, menggantikan, ataupun menentang pesan verbal. Pesan nonverbal lebih dipercaya dibandingkan pesan verbal dalam kasus jika ada ketidaksesuaian antara kedua pesan (Tubbs \& Moss, 2012:114).

Kelebihan pada ekspresi ini ditonjolkan dalam public speaking, mengingat tunarungu memiliki keterbatasan dalam komunikasi verbal. Melalui ekspresi peserta memberikan tekanan pada bagian cerita yang penting untuk diketahui audiens, melalui gerakan mata, bibir, dan posisi tangan. Beberapa peserta menampilkan ekspresi berlebih agar pendengar memahami apa yang dikatakannya. Ekspresi perlu dikelola sesuai dengan pesan yang ingin disampaikan. Pesan sedih didukung dengan ekspresi sedih atau informasi menggembirakan ditampilkan dengan ekspresi gembira pada takaran yang tepat.

Gestur lainnya yaitu gerakan anggota tubuh, postur, eye contact, membantu peserta dalam penyampaian informasi. Kata-kata merupakan senjata yang dapat menghibur atau mengubur. Ada frasa yang mengandung hipnosis dapat menurunkan gelombang otak, manusia mengalami kondisi trans, sehingga manusia hanya fokus pada satu sumber (Hojanto, 2016:129-130). Salah satu peserta secara natural dapat membacakan puisi juga bercerita dengan menampilkan gestur yang mampu membawa audiens menyimak penampilannya secara utuh dan terbawa suasana. Bagi siswa tunarungu, menyampaikan pesan yang baik menggunakan bahasa isyarat tidak selamanya menjadi batas yang sulit dilampaui dengan mengoptimalkan kelebihan yang dimiliki tunarungu.

Setiap pembicara memiliki karakter, diantaranya ceria, lembut, kharismatik, berapi-api. Begitupun dengan peserta pelatihan, mereka memiliki karakter masingmasing. Fasilitator menemukan siswa dengan karakter yang beragam dan mengarahkan agar peserta tampil sesuai karakter masingmasing. Peserta berkarakter serius dan berapi-api diarahkan untuk menguasai teknik pidato, seorang yang berkarakter humoris diarahkan untuk mendalami teknik stand up comedy, dan sebagainya.

Disadari pula menghadapi audiens memiliki tantangan tersendiri dalam public speaking, peserta berlatih menghadapi tipikal audiens dan reaksinya. Tipikal audiens 
diantaranya, tipe pembelajar, tipe penyimak, tipe pengkritik, tipe penghibur, dan tipe no response (Hojanto,2016:70-80). Peserta berlatih untuk menghadapi dinamika reaksi audiens selama tampil. Peserta yang mempunyai spontanitas tinggi mudah beradaptasi dengan situasi tersebut. Sebagian besar siswa tidak siap saat ditertawakan, dikritik, dan didiamkan oleh audiens, akibatnya tiba-tiba peserta lupa materi, grogi, dan tidak menguasai panggung. Solusinya peserta berlatih untuk merespon reaksi audiens sewajarnya, menarik nafas panjang, mengolah dan menata pikiran.

Kesan pertama dalam tampilan public speaking dapat menghipnotis audiens, peserta berlatih memberi pembukaan yang powerfull dan menarik perhatian audiens untuk menyimak lebih lanjut. Pembukaan dapat dilakukan dengan mempertimbangkan visual impact (Hojanto, 2016:85). Peserta pelatihan mempraktikkan teknik ini diantaranya berpantomim. Audiens tertarik dan antusias menyimak. Teknik pembukaan powerfull lainnya yaitu melemparkan humor, menyajikan fakta mengejutkan, melayangkan pujian, atau bercerita. Beberapa peserta mempraktikkan teknik-teknik tersebut.

Pembukaan yang berkesan dapat menarik perhatian audiens menyimak materi yang akan disampaikan oleh public speaker, sementara itu penutupan yang sempurna dimaksudkan untuk memberikan kesan akhir yang baik pada seluruh penampilan, ada kalimat atau momen yang diingat oleh audiens. Penutupan yang berkesan dapat dilakukan dengan cara mereview poin-poin materi, ajakan, himbauan, cerita, pantun, puisi, bahkan lagu (Hojanto,2016:112-112). Peserta pelatihan belum maksimal mempraktikkan teknik ini. Perlu latihan dan pembiasaan menutup interaksi yang lebih berkesan.

Ketika berbicara di depan umum, seringkali terjadi peristiwa yang tidak terduga, seperti kesalahan teknis, materi terhapus di laptop, listrik padam, dan sebagainya. Peserta dilatih untuk menghadapi situasi-situasi ini, karena public speaker tidak pernah mengetahui situasi yang tidak terkendali, namun public speaker diharapkan memiliki trik dan berbagai upaya untuk mengendalikannya agar penampilan tetap berjalan dengan baik.

Penampilan fisik, seperti cara berpakaian, tampilan warna, aksesoris, bau badan, makeup, kebersihan, menjadi faktor pendukung yang penting, hal ini memberikan kesan pertama yang tidak terlupakan di benak audiens. Pada kesan pertama audiens bisa berpersepsi apa saja tentang diri pembicara hanya dengan melihat tampilan fisik. Penampilan fisik juga disesuaikan dengan tema materi yang dibawakan, situasi acara 
formal atau informal, dan segmen audiens yang hadir. Peserta perlu diberikan pelatihan kepribadian yang didalamnya mengupas tentang body language yang menarik, cara berpakaian, dan cara bermake-up yang sesuai. Setelah mengikuti pelatihan, fasilitator memberikan feedback berupa apresiasi dan saran dalam perbaikan penampilan public speaking. Peserta juga diminta untuk membuat kembali satu tampilan public speaking dalam format video yang dilaksanakan di SLB B Yakut Purwokerto.

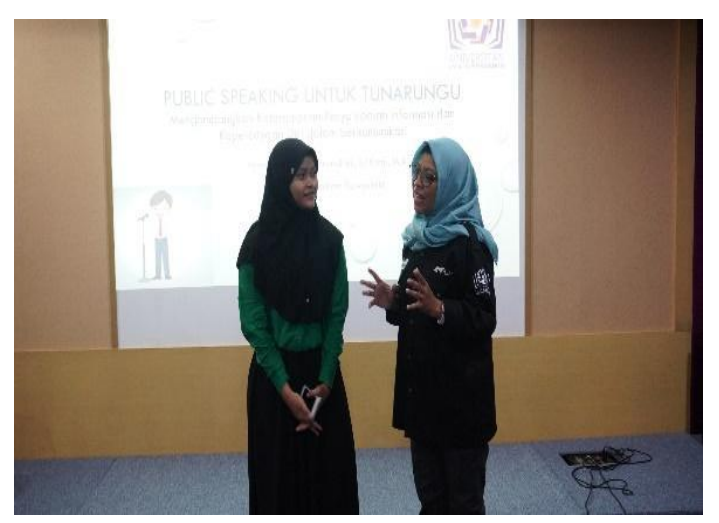

Sumber: Dokumentasi Penulis, 2020

Gambar 4. Fasilitator memberikan feedback pada peserta pelatihan

Fasilitator mengevaluasi dengan membandingkan penampilan sesaat setelah diberikan materi dengan tugas berupa video yang dikerjakan setelah mendapatkan feedback dari fasilitator. Ada perubahan penampilan siswa setelah mendapatkan saransaran perbaikan. Perubahan berupa tata komunikasi isyarat yang lebih menarik, ekspresi yang ditampilkan cenderung terkontrol. Tim fasilitator memperhatikan peningkatan dalam kepercayaan diri walaupun tidak signifikan dan patut diapresiasi mengingat kepercayaan diri tidak dapat dibentuk dalam waktu relatif singkat, perlu latihan secara berkesinambungan. Penampilan terlihat lebih menarik dari segi berpakaian, aksesoris yang digunakan, dan hal lain yang mendukung penampilan saat menjadi public speaker.

Metode story telling dalam praktik public speaking memudahkan peserta untuk belajar berbicara di depan umum karena pelatihan ini merupakan perdana bagi peserta. Fasilitator menyarankan tema pengalaman pribadi di mana peserta mengalaminya sendiri sehingga lebih mudah untuk disampaikan. Secara umum peserta nyaman menggunakan metode ini.

Pelatihan public speaking ini secara keseluruhan menjadi solusi bagi pihak SLB B Yakut Purwokerto, untuk peningkatan keterampilan siswanya dalam berkomunikasi dan kepercayaan diri.

\section{KESIMPULAN}

Berkomunikasi tidak hanya sekedar berbicara, berkata-kata atau bercerita, dalam komunikasi pesan yang disampaikan selayaknya dimengerti oleh lawan bicara, sehingga dapat mengubah perilaku bagi penerima pesan. Tunarungu memiliki keterbatasan berkomunikasi secara verbal. 
Pelatihan public speaking dapat memberikan sumbangsih mengatasi tantangan tersebut. Pada pelatihan Public speaking, peserta berlatih cara membangun kepercayaan diri, mengatasi berbagai tipikal audiens, membuka dan menutup acara dengan kesan yang baik, mengatasi berbagai situasi darurat saat tampil, dan menjadikan penampilan diri yang menarik di benak audiens.

Peserta pelatihan, masing-masing memiliki bakat, karakter, keunikan dan kelebihan. Diantara peserta ada yang sangat baik dalam mengolah ekspresi, memiliki bahasa tubuh yang menarik sehingga audiens memberi perhatian penuh pada materi yang disampaikan. Peserta lainnya memiliki kekuatan dalam menghibur, interaksi antara public speaker dengan audiens menjadi menyenangkan dan interaktif. Keunikan dan kekuatan ini perlu dikembangkan dengan berlatih secara kontinyu.

Pelatihan yang dilaksanakan selama tiga hari ini memberikan dampak positif bagi peserta. Hasil evaluasi, peserta mengalami peningkatan dalam penampilan, rasa percaya diri, dan kejelasan pesan ketika menyampaikan informasi terlebih di depan audiens. Metode pembelajaran story telling yang digunakan dalam pelatihan sudah cukup sesuai dengan kondisi tuna rungu, namun perlu ditingkatkan seperti menggunakan alat peraga atau bentuk pendukung visual lainnya.

Keterampilan public speaking perlu ditingkatkan, karena keterampilan tersebut memerlukan latihan secara kontinyu. Peserta perlu tampil dalam berbagai acara, mengikuti ajang kompetisi yang berkaitan dengan public speaking. Selain itu peserta perlu meningkatkan cara berpenampilan fisik yang menarik untuk mendukung, seperti mengikuti pelatihan kepribadian dan beauty class.

Keterampilan lain yang perlu ditingkatkan oleh peserta yaitu mampu untuk menguasai materi saat tampil. Sebagian besar peserta masih menggunakan catatan dan sesekali membacanya. Menguasai materi berbeda dengan menghafal. Peserta perlu berlatih memahami materi dan mengingat poin-poin yang akan disampaikan. Memperkaya materi dapat dilakukan dengan membaca berbagai referensi seputar informasi yang akan disajikan. Peserta juga dapat berdiskusi dengan orang yang memiliki pengetahuan sejenis. Inti dari penguasaan materi adalah menggali ilmu dan mengembangkan wawasan seluas-luasnya.

Kendala selama pelaksanaan pelatihan yaitu lebih kepada media penyampaian materi. Meskipun materi dapat dipahami dengan baik oleh peserta, penyampaian materi hendaknya dapat dibuat lebih interaktif secara visual, seperti menggunakan animasi 
bergerak atau video pembelajaran agar lebih menarik. Media pembelajaran secara visual dapat mendukung pemahaman siswa tunarungu terhadap materi pelatihan.

Peserta juga dapat tampil dibantu dengan gambar-gambar dan video menarik. Selain itu peserta dapat meningkatkan kemampuan menggali gagasan kreatif, berbicara tanpa teks, dan berlatih retorika secara impromptu (berbicara tanpa persiapan atau pembuatan naskah terlebih dahulu). Metode impromptu dapat melatih kelugasan menyampaikan pesan dan materi dapat dikembangkan sesuai situasi dan kondisi audiens.

Metode pembelajaran/praktik story telling dapat ditingkatkan dengan berlatih melakukan orasi, pidato, menjadi MC (Master of Ceremony) formal dan informal, serta keterampilan mengajar. Peningkatan keterampilan tersebut dapat memberikan bekal bagi siswa tunarungu untuk mengambil peran di masyarakat dan dunia kerja.

Pelatihan public speaking pada akhirnya dapat membangun konsep diri positif bagi siswa tunarungu. Ini merupakan implikasi sertaan yang bermanfaat bagi peningkatan rasa percaya diri siswa tunarungu di SLB B Yakut Purwokerto.

\section{UCAPAN TERIMAKASIH}

Pengabdian Kepada Masyarakat ini terlaksana atas bantuan dan partisipasi berbagai pihak terutama SLB B Yakut Purwokerto sebagai mitra. Terima kasih kami haturkan kepada Ibu Netti selaku kepala sekolah serta rekan-rekan guru yang kami hormati, atas kesempatan yang diberikan. Kami juga mengucapkan terima kasih kepada Universitas Amikom Purwokerto atas dukungan fasilitas sehingga Pengabdian Kepada Masyarakat ini dapat terlaksana, serta Ibu Dr. Ade Tuti Turistiati, MIRHRM selaku Kaprodi Ilmu Komunikasi Universitas Amikom Purwokerto yang berkenan membuka acara. Terima kasih kepada Merliana Nur Khasidah dan Pramudita Nugraha Adi Kristika, mahasiswa Ilmu Komunikasi Universitas Amikom Purwokerto yang turut berpartisipasi dalam tim, serta seluruh pihak yang membantu terlaksananya pelatihan ini.

\section{REFERENSI}

Hojanto, O. (2016). Public Speaking Mastery. Jakarta: Gramedia Pustaka Utama.

Mulyana, D. (2019). Ilmu Komunikasi Suatu Pengantar. Bandung: Remaja Rosda Karya.

Noer, M. (2017). Mengasah Kemampuan Public Speaking. Diambil dari presentasi Net Website https://www.presentasi.net/author/noer pressadm/ 
Rakhmat, J. (2019). Psikologi Komunikasi Edisi Revisi. Bandung: Simbiosa Rekatama Media.

Sirait, C. B., Sirait, B. (2016). The Power Of Public Speaking. Jakarta: Elex Media Komputindo.

Tubbs, S. L., Moss, S. (2012). Human Communication Prinsip-Prinsip Dasar (Edisi Bahasa Indonesia). Bandung: Remaja Rosda Karya.

Turistiati, A. T., \& Ramadhan, H. F. A. (2019). Pelatihan Soft Skills Dan Pendampingan Siswa-Siswi SMK Di Kota Bogor Untuk Persiapan Memasuki Dunia Kerja. Jurnal Komunitas: Jurnal
Pengabdian kepada Masyarakat, 1(2), 1-8.

Undang-undang No.23 Tahun 2002 Tentang Perlindungan Anak.

Undang-undang Disabilitas No.8 Tahun 2016.

Wakhyudi, Y. (2019). Kiat Praktis Kuasai Public Speaking, Tips dan Trik Berbicara di Depan Umum dengan Asyik dan Memukau. Yogyakarta: Checklist.

Helen Keller Biography. Retrieved From https:// www. afb. org/ about-afb /history/ helen- keller/ biography-andchronology/ biography 